\title{
Fibroblast growth factor in gastroprotection and ulcer healing: interaction with sucralfate
}

Stanislaw J Konturek, Tomasz Brzozowski, Jolanta Majka, Aleksandra Szlachcic, Wladyslaw Bielanski, Jerzy Stachura, Wilhelm Otto

\begin{abstract}
The study was designed to determine the gastroprotective and ulcer healing efficacy of basic transforming growth factor (bFGF) and to assess whether this peptide contributes to the action of sucralfate on the rat stomach. Application of human recombinant bFGF (1-100 $\mu \mathrm{g} / \mathrm{kg} / \mathrm{hour}$ subcutaneously) failed to affect the formation of acute gastric lesions induced by $100 \%$ ethanol and acidified aspirin but reduced the stress induced by gastric lesions. Sucralfate $(100-200 \mathrm{mg} / \mathrm{kg}$ given orally) protected gastric mucosa against the ethanol, aspirin, and stress induced acute gastric lesions but the addition of bFGF (100 $\mu \mathrm{g} / \mathrm{kg}$ subcutaneously or intragastrically) failed to affect sucralfate induced protection against ethanol or aspirin but increased that against stress. Administration of bFGF (3-300 $\mu \mathrm{g} / \mathrm{kg} / \mathrm{day}$ ) by an intragastric or an intraperitoneal route or sucralfate $(400 \mathrm{mg} / \mathrm{kg} /$ day $)$ orally to rats with acetic acid induced gastric ulcers, enhanced the healing rate of these ulcers during seven day treatment in a dose dependent manner. This was accompanied by a pronounced increase in the number of capillaries and myofibroblasts and in DNA synthesis and DNA and RNA concentrations in the granulation tissue in the ulcer area. $\left[{ }^{125} I\right] b F G F$ $(1 \mu \mathrm{Ci})$ applied subcutaneously or intragastrically accumulated in two to threefold higher amounts in the ulcer area than in the intact mucosa, particularly in rats treated with sucralfate. Concurrent treatment with indomethacin $(2 \mathrm{mg} / \mathrm{kg}$ intraperitoneally) delayed ulcer healing and reduced the binding of labelled bFGF to the ulcer area, angiogenesis, and DNA synthesis by sucralfate. Addition of $\left[{ }^{125} \mathrm{I}\right] \mathrm{bFGF}$ to sucralfate at various $\mathrm{pHs}$ resulted in the coprecipitation of bFGF by sucralfate in a $\mathbf{p H}$ dependent manner from about $10 \%$ at $\mathrm{pH} 7 \cdot 0$ to $90 \%$ at $\mathrm{pH} 1 \cdot 5$. Thus bFGF shows little protective activity and is not essential for gastroprotection afforded by sucralfate but plays an important part in healing of gastric ulcers possibly due to its growth promoting and angiogenic actions.

(Gut 1993; 34: 881-887)
\end{abstract}

University Physiology

School, Krakow, Poland

S J Konturek

T Brzozowsk

J Majka

A Szlachcic

W Bielanski

J Stachura

W Otto

Correspondence to:

Professor S J Konturek, Institute of Physiology, University Medical School 31-531 Krakow, ul

Grzegorzecka 16, Poland.

Accepted for publication 11 November 1992

Growth factors such as epidermal growth factor (EGF), transforming growth factor (TGF), platelet derived growth factor (PDGF), and fibroblast growth factor (FGF) are potent mitogenic peptides expressed in various tissues including the gastrointestinal tract. ${ }^{12}$ Both EGF and TGF were identified in the gastric mucosa and found to promote cell proliferation, processes. ${ }^{36}$ An interaction was reported between EGF and antiulcer drugs such as sucralfate $^{78}$ and antacids ${ }^{9}$ in healing of chronic gastroduodenal ulcerations.

Fibroblast growth factors exist in acidic (aFGF) and basic (bFGF) forms and are expressed in most cells of the body, ${ }^{10}{ }^{12}$ especially in endothelial cells, fibroblasts, and macrophages. ${ }^{1314}$ They are stored within the basal membrane or extracellular matrix ${ }^{1516}$ and released in an active form to stimulate tissue repair and healing. ${ }^{17}{ }^{18}$ Oral treatment with acid resistant bFGF was recently reported to accelerate healing of gastroduodenal ulcers induced by acetic acid or cysteamine in rats. ${ }^{1920}$

Basic FGF is more potent than aFGF in an in vitro system ${ }^{21}$ but no information is available on its efficacy in mucosal protection, repair, and healing processes.

The purposes of the present study were (1) to determine the binding of human recombinant bFGF to the intact and ulcerated gastric mucosa; (2) to assess the protective activity of bFGF against the damage by various irritants and stress; (3) to examine the efficacy of bFGF in healing of gastric ulcers; and (4) to evaluate the interaction of bFGF with sucralfate in the gastroprotection and healing of gastric ulcerations in rats.

\section{Materials and methods}

ANIMALS

Male Wistar rats weighing about $250 \mathrm{~g}$ were fitted with chronic gastric fistulas and used about four weeks later. Before each experiment, the animals were fasted for around 18 hours and placed in individual (Bollman type) cages to maintain the minimum restraint necessary. The fistula was opened and the stomach was rinsed gently with about $5 \mathrm{ml}$ of tap water at $37^{\circ} \mathrm{C}$. Basal gastric secretion was collected for 60 minutes, and bFGF was infused subcutaneously (at a rate of $4 \mathrm{ml} /$ hour) in various doses ranging from 1 to $100 \mu \mathrm{g} / \mathrm{kg} /$ hour with a peristaltic pump; each dose was infused for 60 minutes in one day's test. In tests with intragastric administration of bFGF, the peptide was dissolved in $1 \mathrm{ml}$ of saline and instilled into the stomach via the cannula of mucosal repair, gastroprotection, and healing the gastric fistula and the fistula was closed for 30 minutes. Then the collection of gastric juice was restarted and continued for a final 60 minutes. Only the $100 \mu \mathrm{g} / \mathrm{kg}$ dose of bFGF was given by the intragastric route. For comparison, omeprazole $(30 \mathrm{mg} / \mathrm{kg}$ ) was administered subcutaneously. In control tests, vehicle (saline) was infused at the same volume and in the same manner as in tests with bFGF. 
Gastric juice was collected in 30 minute aliquots, the volume of the juice was measured, and acid concentration was assessed by titration with $100 \mathrm{mM} \mathrm{NaOH}$ to $\mathrm{pH} 7 \cdot 0$ with an autoburette (Radiometer, Copenhagen). Acid output was expressed as $\mu \mathrm{M}$ per 30 minutes as described. ${ }^{3}$ Pepsin output was also measured in each sample by Anson's haemoglobin method and expressed in $\mathrm{mg} / 30$ minutes.

EXPERIMENTS WITH ACUTE GASTRIC LESIONS Acute gastric lesions were induced by ethanol, aspirin, or stress as described before.$^{622}$ Absolute ethanol was introduced by an intragastric route in a $1.5 \mathrm{ml}$ volume with a metal orogastric tube. The animals were anaesthetised one hour after ethanol administration to allow measurement of gastric blood flow by laser Doppler flowmetry (Laserflo, model BPM 403A, Vasamedics Inc, St Paul, $M N$ ) as described previously. ${ }^{23}$ They were then killed. The stomach was removed and the area of gastric lesions was measured by planimeter (Morphomat, Carl Zeiss Berlin, Germany) by two investigators under blinded conditions.

Aspirin was introduced by an intragastric route in a dose of $200 \mathrm{mg} / \mathrm{kg}$ in $250 \mathrm{mM} \mathrm{HCl}$. The animals were anaesthetised three hours later and gastric blood flow and area of gastric lesions were measured as previously described.

Stress ulcerations were evoked by placing the animals in stress cages and immersion in a water bath at $23^{\circ} \mathrm{C}$ for six hours to the xyphoid level as described by Takeuchi et al. ${ }^{22}$ Immediately after the stress, the animals were anaesthetised to enable measurement of gastric blood flow. The stomach was then removed and the number of gastric lesions was counted.

Several groups of eight to 10 rats were used in studies with each ulcerogen ( $100 \%$ ethanol, acidified aspirin, and stress). These were (1) vehicle (saline) given by intragastric instillation or subcutaneous infusion followed 30 minutes later by ulcerogen; (2) bFGF infused subcutaneously in a dose of $100 \mu \mathrm{g} / \mathrm{kg} /$ hour followed 30 minutes later by ulcerogen; (3) bFGF given by an intragastric route at a dose of $100 \mu \mathrm{g} / \mathrm{kg}$ followed 30 minutes later by ulcerogen; (4) sucralfate $(100 \mathrm{mg} / \mathrm{kg}$ by intragastric instillation) followed 30 minutes later by ulcerogen; (5) bFGF infused subcutaneously in a dose of 100 $\mu \mathrm{g} / \mathrm{kg} /$ hour and sucralfate $(100 \mathrm{mg} / \mathrm{kg}$ by intragastric instillation) followed 30 minutes later by ulcerogen; and (6) intragastric bFGF $(100 \mu \mathrm{g} /$ $\mathrm{kg})$ given in combination with sucralfate $(100$ $\mathrm{mg} / \mathrm{kg}$ ) followed 30 minutes later by ulcerogen. Sucralfate or bFGF was dissolved in saline and given by the intragastric route in a volume of $1 \mathrm{ml}$ or infused subcutaneously at $4 \mathrm{ml} /$ hour. Saline was also used as vehicle and was administered in the same manner and in the same volume as the test substances. Basic FGF and sucralfate in suspension were supplied by $\mathrm{Dr}$ E Gehrls (Merck E, Darmstadt, Germany).

EXPERIMENTS WITH ACETIC ACID INDUCED GASTRIC ULCERATIONS

Gastric ulcers were induced with our modification $^{9}$ of the acetic acid method originally des- cribed by Takagi et al. ${ }^{24}$ The animals were fasted for 24 hours and then their abdomen was opened and the stomach exposed under light ether anaesthesia. A plastic mould of $6 \mathrm{~mm}$ diameter was applied tightly to the serosal surface of the anterior wall of the stomach just proximal to the antral gland area and $70 \mu \mathrm{l} 100 \%$ acetic acid was poured through the mould on to the surface of the stomach for 20 seconds. This method caused an immediate necrosis of the entire thickness of gastric wall under the area of acetic acid application (about $28 \mathrm{~mm}^{2}$ ) but without perforation or penetration of ulcers to the surrounding organs as in the original technique. ${ }^{24}$ After the application of acetic acid, animals were allowed to recover from the anaesthesia and received only water on the day of operation (day 0 ). Then they were divided into various groups and given unlimited normal rat food and water for the next seven days.

Several groups, each consisting of eight to 10 rats with gastric ulcers, were used in two series, $A$ and $B$. In series A, group I rats were treated with vehicle (saline, $1 \mathrm{ml}$ given by intragastric route three times daily) only (control); group II rats were given intragastric $\mathrm{bFGF}(3,30$, or 300 $\mu \mathrm{g} / \mathrm{kg} /$ day in three equal doses, each dose dissolved in $1 \mathrm{ml}$ of saline); group III rats were given bFGF by intraperitoneal injection $(3,30$, or 300 $\mu \mathrm{g} / \mathrm{kg} /$ day in three equal doses); group IV rats were treated with intragastric sucralfate (added to drinking water, $400 \mathrm{mg} / \mathrm{kg} /$ day); group V rats were treated with a combination of intragastric bFGF (30 $\mu \mathrm{g} / \mathrm{kg} /$ day in three equal doses) plus sucralfate; group VI rats were treated with intraperitoneal $\mathrm{bFGF}(30 \mu / \mathrm{kg} /$ day in three equal doses); and for comparison group VII rats were treated with omeprazole $(60 \mathrm{mg} / \mathrm{kg} / \mathrm{day}$ into the peritoneum in two equal doses each dissolved in $1 \mathrm{ml}$ of saline).

Rats of series B were divided into group I treated with vehicle (saline) alone; group II treated with daily intraperitoneal injection of indomethacin $(2 \mathrm{mg} / \mathrm{kg})$; group III treated with sucralfate (400 mg/kg/day); and group IV, treated with a combination of indomethacin $(2 \mathrm{mg} / \mathrm{kg}$ ) plus sucralfate $(400 \mathrm{mg} / \mathrm{kg})$.

To evaluate the effects of bFGF and sucralfate on ulcer healing, the animals of series A were treated for seven days and then anaesthetised with ether. The abdomen was opened and the stomach was exposed to assess the mucosal blood flow at the ulcer margin, ulcer bed, and adjacent intact mucosa. Then the stomach was removed and opened for the measurement of ulcer area. ${ }^{8}$ All measurements were performed by technical personnel unaware of the treatment given.

Samples of the mucosa from the ulcer margin including the granulation tissue and the adjacent intact mucosa were excised in each rat of series A for biochemical analysis (DNA synthesis and DNA and RNA content) and histological assessment of number of capillaries and myofibroblasts.

HISTOLOGICAL EVALUATION OF THE MUCOSA AT THE ULCER AREA

The mucosal samples were fixed in $10 \%$ buffered formalin and embedded in paraffin. The paraffin 
sections were stained with haematoxylin and eosin. Histological examination was performed by two pathologists unaware of the treatment. Quantitative assessment of microvessel profiles was performed under $500 \times$ magnification and expressed as the mean number of microvessels per microscopical field. Number of fibroblasts was also calculated per microscopical field at $1000 \times$ magnification. Mean values were calculated from at least three fields on each slide.

\section{BIOCHEMICAL ANALYSIS OF GROWTH OF INTACT} AND ULCERATED MUCOSA

The portions of the tissue excised from the ulcer margin and from the adjacent intact mucosa were weighed and the rate of DNA synthesis was measured by incubating the tissue at $30^{\circ} \mathrm{C}$ for 30 minutes in Eagle's minimal essential culture medium containing $2 \mu \mathrm{Ci} / \mathrm{ml}$ of $\left[{ }^{3} \mathrm{H}\right]$ thymidine (Amersham, UK) as described previously. ${ }^{3}$ The incorporation of labelled thymidine into filtrate containing DNA was measured in a Beckman liquid scintillation system; DNA synthesis was expressed as disintegrations per minute (dpm)/ $\mu \mathrm{g}$ DNA. The DNA and RNA concentrations were also determined in each sample according to a method described in detail elsewhere ${ }^{25}$ and expressed in $\mu \mathrm{g} / 100 \mathrm{mg}$ of tissue.

STUDIES ON BINDING OF [ ${ }^{125}$ I] bFGF TO SUCRALFATE AND TO THE GASTRIC MUCOSA

The adsorption of bFGF to sucralfate was examined in vitro by adding $100 \mu$ l of sucralfate (about $20 \mathrm{~g} / \mathrm{l}$ ) or vehicle (control) to $500 \mu \mathrm{l}$ of [225]bFGF (about $30000 \mathrm{cpm}$ ) dissolved in phosphate buffer (with $0 \cdot 1 \%$ bovine albumin) adjusted to $\mathrm{pHs}$ ranging from $1 \cdot 5$ to $7 \cdot 5$. The mixtures were incubated for 30 minutes at $25^{\circ} \mathrm{C}$ and centrifuged for 10 minutes. The bFGF bound to sucralfate was harvested and the radioactivity was counted for 1 minute in a $\gamma$ scintillation counter (LKB Wallace, Wien, Austria). The results are expressed in per cent of [ $\left.{ }^{125} \mathrm{I}\right]$ bFGF coprecipitated by sucralfate or vehicle $v$ $\mathrm{pH}$ of the incubation mixture.

In rats of series B (treated with sucralfate, or indomethacin, or both), each group was subdivided and one subgroup was injected intravenously with $1 \mu \mathrm{Ci}$ of [ $\left.{ }^{125} \mathrm{I}\right] \mathrm{bFGF}$ before killing. Two areas of about $40 \mathrm{~mm}^{2}$, one including the gastric ulcer and the other a similar area of adjacent intact mucosa were excised and the radioactivity of each excised piece was measured and expressed as cpm per $100 \mathrm{mg}$ of tissue. The ratio of radioactivity of ulcer area $v$ intact mucosa was calculated for each group of rats. In another subgroup similar $40 \mathrm{~mm}^{2}$ areas were placed in 0.5 $\mathrm{ml}$ of $0.05 \mathrm{M}$ phosphate buffer $\mathrm{pH} \mathrm{7.0}$ containing $0.5 \% \mathrm{BSA}$ and aprotonin with addition of [225] bFGF (about $6000 \mathrm{cpm}$ in $0.1 \mathrm{ml}$ ) were incubated at $25^{\circ} \mathrm{C}$ for 60 minutes. The reaction was stopped by the addition of ice cold phosphate. Each tube was centrifuged at $1500 \mathrm{~g}$ for 10 minutes and after separation, the radioactivity of the pellet was counted in an LKB 1271 RIAGAMMA counter (Turku, Finland). Nonspecific bFGF binding was estimated by incubating tissue samples to which $1 \mu \mathrm{g}$ of non- labelled bFGF was added before the addition of $\left[{ }^{125} \mathrm{I}\right] \mathrm{bFGF}$. The results were expressed as means of cpm of tissue bound [ $\left.{ }^{125} \mathrm{I}\right] \mathrm{bFGF}$. Non-specific bFGF binding did not exceed $20 \%$ of total radioactivity added. The ratio of the radioactivity bound to the ulcerated and to the intact mucosa was calculated for each group of animals of the B series.

\section{STATISTICS}

The data are expressed as mean (SEM). Comparisons between groups of parametric data were made by Student's $t$ test for unpaired data or analysis of variance and Duncans multiple range tests. p Values $<0.05$ were taken as significant.

\section{Results}

EFFECTS OF bFGF ON GASTRIC ACID SECRETION Basal gastric acid and pepsin outputs from the gastric fistulas of conscious rats treated with vehicle averaged 131 (16) $\mu \mathrm{mol} / 30$ minutes and $0.95(0.12) \mathrm{mg} / 30$ minutes respectively. Infusion of bFGF subcutaneously in various doses (1-100 $\mu \mathrm{g} / \mathrm{kg} /$ hour) did not significantly alter gastric acid or pepsin secretion, although at the highest dose of bFGF $(100 \mu \mathrm{g} / \mathrm{kg})$ gastric secretion tended to decline; acid output fell to 103 (15) $\mu \mathrm{mol} / 30$ minutes and pepsin output fell to 0.76 $(0 \cdot 17)$. The administration of bFGF $(100 \mu \mathrm{g} / \mathrm{kg})$ directly into the stomach also failed to significantly alter gastric acid or pepsin secretion and these results have not been included. For comparison, omeprazole given subcutaneously at a dose of $30 \mathrm{mg} / \mathrm{kg}$ resulted in almost complete inhibition of acid output (12 (2) $\mu \mathrm{mol} / 30$ minutes) and pepsin output $(0 \cdot 15(0.04) \mathrm{mg} / 30$ minutes).

EFFECTS OF bFGF AND SUCRALFATE ON ACUTE GASTRIC LESIONS INDUCED BY 100\% ETHANOL, ACIDIFIED ASPIRIN, OR STRESS

In tests with vehicle plus $100 \%$ ethanol (control), the mean number of gastric lesions was $15(3)$ and the mean area of gastric lesions averaged 82 (6) $\mathrm{mm}^{2}$ per rat (Table I). When bFGF was administered subcutaneously or by intragastric route in a dose of $100 \mu \mathrm{g} / \mathrm{kg}$, there was no significant change in the ethanol induced gastric lesions. Pretreatment with sucralfate $(100 \mathrm{mg} / \mathrm{kg})$ resulted in a significant decrease in lesion area to about $60 \%$ of the control area. The combination of bFGF given subcutaneously or by an intragastric route with sucralfate administered intragastrically did not significantly influence the reduction in the ethanol induced lesion area compared with that obtained with sucralfate alone (Table I).

Gastric blood flow averaged about $62(5) \mathrm{ml} /$ $\mathrm{min} / 100 \mathrm{~g}$ of tissue in the oxyntic portion of intact mucosa. After exposure of the mucosa to $100 \%$ ethanol, this was reduced by about $65 \%$ and the reduction was not significantly altered by the administration of bFGF. Pretreatment with sucralfate $(100 \mathrm{mg} / \mathrm{kg})$ significantly enhanced gastric blood flow but combination with bFGF did not influence this enhancement (Table I). 
TABLE I Effect of vehicle, $b F G F$, sucralfate, and the combination of FGF plus sucralfate on the mean lesion number, mean lesion area, and gastric blood flow in rats treated with $100 \%$ ethanol, acidified aspirin, or subjected to water immersion and restraint stress. Results are from eight experiments on eight rats

\begin{tabular}{|c|c|c|c|}
\hline Test & $\begin{array}{l}\text { Lesions } \\
\text { No }(S E M)\end{array}$ & $\begin{array}{l}\text { Lesion area } \\
m^{2}(S E M)\end{array}$ & $\begin{array}{l}\text { Gastric blood flow } \\
\mathrm{ml} / \mathrm{min} / 100 \mathrm{~g} \\
(\mathrm{SEM})\end{array}$ \\
\hline 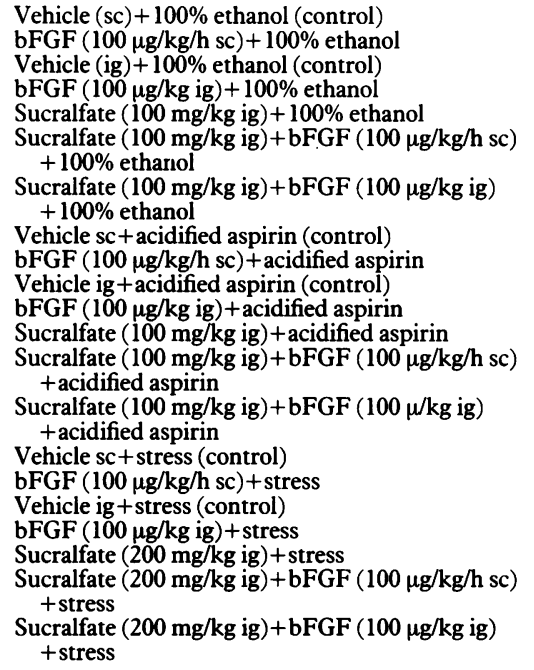 & $\begin{array}{l}15(3) \\
16(4) \\
15(4) \\
14(4) \\
8(1)^{\star} \\
10(2)^{\star} \\
10(2)^{\star} \\
13(3) \\
14(2) \\
13(3) \\
12(3) \\
7(1 \cdot 5)^{\star} \\
8(2)^{\star} \\
7(3)^{\star} \\
9(2) \\
6(1) \\
10(3) \\
7(2) \\
4(0 \cdot 3)^{\star} \\
2(0 \cdot 1) \dagger \\
4(0 \cdot 5)^{\star}\end{array}$ & $\begin{array}{l}81 \cdot 7(6 \cdot 2) \\
78 \cdot 3(4 \cdot 1) \\
80 \cdot 0(5 \cdot 2) \\
80 \cdot 1(5 \cdot 8) \\
32 \cdot 5(4 \cdot 3)^{\star} \\
40 \cdot 2(6 \cdot 5)^{\star} \\
38 \cdot 9(5 \cdot 5)^{\star} \\
73 \cdot 3(7 \cdot 5) \\
75 \cdot 0(5 \cdot 5) \\
74 \cdot 4(5 \cdot 1) \\
71 \cdot 8(6 \cdot 4) \\
42 \cdot 1(3 \cdot 8)^{\star} \\
45 \cdot 8(5 \cdot 8)^{\star} \\
44 \cdot 3(6 \cdot 2)^{\star} \\
2 \cdot 2(0 \cdot 4) \\
1 \cdot 4(0 \cdot 2) \\
2 \cdot 4(0 \cdot 4) \\
1 \cdot 7(0 \cdot 3) \\
1 \cdot 8(0 \cdot 2)^{\star} \\
0 \cdot 8(0 \cdot 1) \dagger \\
0.95(0 \cdot 1)^{\star}\end{array}$ & $\begin{array}{l}22(5) \\
24(4) \\
22(4) \\
21(3) \\
32(3)^{\star} \\
31(4)^{\star} \\
28(2) \\
20(5) \\
24(4) \\
21(4) \\
22(5) \\
29(2) \\
30(3)^{\star} \\
27(2) \\
23(3) \\
30(2) \\
27(4) \\
24(3) \\
31(2)^{\star} \\
38(3) \dagger \\
32(1)^{\star}\end{array}$ \\
\hline
\end{tabular}

* Significant change below the value obtained with vehicle+ulcerogen alone. tSignificant change below the value obtained with sucralfate plus stress and bFGF plus stress. sc=Subcutaneous; ig=intragastric. of water immersion and restraint stress, gastric lesions appeared as small and scattered haemorrhagic erosions mostly in the oxyntic gland area and this was accompanied by about $63 \%$ reduction in gastric blood flow. Sucralfate $(200 \mathrm{mg} / \mathrm{kg})$ caused a significant reduction (by about $50 \%$ ) in the number and area of gastric lesions and a significant increase in gastric blood flow above that obtained in vehicle treated controls. Pretreatment with bFGF alone $(100 \mu \mathrm{g} / \mathrm{kg} / \mathrm{hour})$ resulted in a small but significant reduction in the number and area of stress lesions. In rats receiving intragastric $\mathrm{bFGF}$, the stress lesions tended to decline but this was not statistically significant. When bFGF given subcutoneously (but not by the intragastric route) was combined with sucralfate, the reduction in gastric lesions was more pronounced than that achieved with sucralfate or bFGF alone (Table I).

\section{EFFECTS OF bFGF ON HEALING OF CHRONIC} GASTRODUODENAL ULCERATIONS IN RATS WITH OR WITHOUT ADMINISTRATION OF INDOMETHACIN

In rats of series A, serosal application of acetic acid resulted in the formation of gastric ulcerations in all rats tested. The initial area of ulcers measured one day after their induction conformed with the size of the mould and averaged $28 \mathrm{~mm}^{2}$. Seven days after induction, the area in vehicle treated animals was $10.4(0.9) \mathrm{mm}^{2}$ (Table II). In rats treated with bFGF at doses of 3-300 $\mu \mathrm{g} / \mathrm{kg}$ per day, there was a dose dependent decrease in the ulcer area (compared with vehicle control). The reduction in the ulcer area after treatment with intraperitoneal bFGF at a dose of $30 \mu \mathrm{g} / \mathrm{kg} / \mathrm{day}$ was comparable with that obtained with omeprazole at a dose of $60 \mathrm{mg} / \mathrm{kg} /$ day - namely, almost complete inhibition of gastric acid secretion (Table II). Sucralfate administered at $400 \mathrm{mg} / \mathrm{kg} /$ day caused similar reductions in ulcer area to that found in rats treated with bFGF at a dose of $30 \mu \mathrm{g} / \mathrm{kg} /$ day. The combination of sucralfate plus bFGF (30 $\mu \mathrm{g} / \mathrm{kg} /$ day) resulted in a decrease in the ulcer area similar to that with sucralfate alone or bFGF alone but the combination of sucralfate plus bFGF injected into the peritoneum resulted in greater reduction in the ulcer area than that

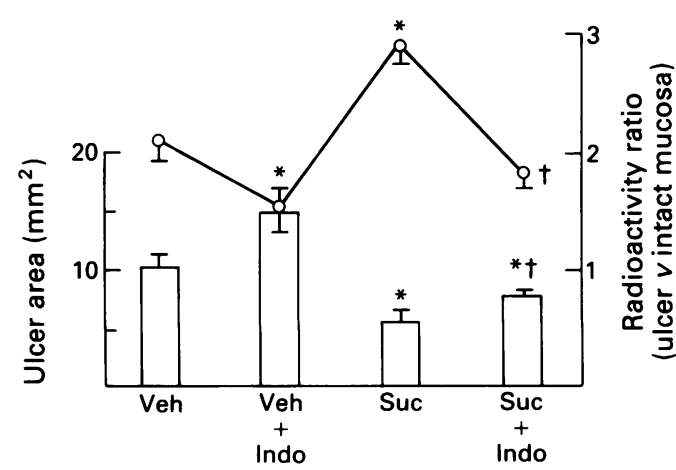

Figure 1: Mean area of gastric ulcers (histogram) and the ratio of radioactivity $(O)$ between the ulcer area and the intact mucosa in rats treated for seven days with vehicle (Veh), indomethacin (Indo; 2 mg/kg/day ip), sucralfate (Suc's 400 $\mathrm{mg} / \mathrm{kg} /$ day ig), or their combination. Results are means (SEM) of six rats. * Significant change compared with the vehicle value; tsignificant change compared with the value obtained from sucralfate alone.

$\star$ Significant change compared with control value in vehicle treated rats.

tSignificant decrease below the value obtained with sucralfate or $\mathrm{bFGF}(30 \mu \mathrm{g} / \mathrm{kg} /$ day ip) alone. ig=Intragastric; ip=intraperitoneal. TABLE II Effects of bFGF and omeprazole on the area of 10 rats 
TABLE III Number of microvessels and myofibroblasts per microscopical field in the granulation tissue at the ulcer margin from rats treated with $b F G F$ alone, sucralfate alone, or bFGF combined with sucralfate

\begin{tabular}{lll}
\hline Treatment & $\begin{array}{l}\text { Capillaries } \\
\text { Mean }(\text { SEM })\end{array}$ & $\begin{array}{l}\text { Myofibroblasts } \\
\text { Mean }(\text { SEM })\end{array}$ \\
\hline Vehicle & $16 \cdot 1(0 \cdot 8)$ & $104(8)$ \\
bFGF (ig) & $21 \cdot 5(1 \cdot 2)^{\star}$ & $113(7)$ \\
bFGF (ip) & $31 \cdot 2(0 \cdot 85)^{\star}$ & $135(11)^{\star}$ \\
Sucralfate & $17 \cdot 0(0 \cdot 64)$ & $112(8)$ \\
bFGF (ig)+sucralfate & $21 \cdot 4(0 \cdot 69)^{\star}$ & $110(8)$ \\
bFGF (ip)+sucralfate & $27 \cdot 6(1 \cdot 2)^{\star}$ & $138(12)^{\star}$ \\
\hline
\end{tabular}

^Significant increase greater than the vehicle value.

No of rats per group $=8-10$; ig=intragastric; ip=intraperitoneal.

attained with sucralfate alone or bFGF alone (Table II).

Gastric blood flow at the ulcer bed was 12 (3) $\mathrm{ml} / \mathrm{minute} / 100 \mathrm{~g}$ and at the ulcer margin - $32(4)$ $\mathrm{ml} / \mathrm{minute} / 100 \mathrm{~g}$, whereas in the adjacent intact mucosa it was $58(7) \mathrm{ml} / \mathrm{minute} / 100 \mathrm{~g}$. A similar profile of gastric blood flow was found in rats treated with sucralfate or omeprazole but in rats given bFGF, especially when injected into the peritoneum alone or in combination with sucralfate, the gastric blood flow at the ulcer margin reached significantly higher values than that in vehicle treated controls (Table II).

In rats of series $B$ receiving daily injection of indomethacin $(2 \mathrm{mg} / \mathrm{kg})$ throughout the seven day period after ulcer induction, the area of gastric ulcers was about $50 \%$ larger than in animals without indomethacin administration (Fig 1). Addition of sucralfate $(400 \mathrm{mg} / \mathrm{kg} /$ day) resulted in a significant reduction in the area compared with vehicle control. In rats receiving the combination of sucralfate plus indomethacin, the area of gastric ulcer was less than the vehicle control but significantly higher than that after the treatment with sucralfate alone.

\section{EFFECTS OF bFGF AND SUCRALFATE ON THE} NUMBER OF CAPILLARIES AND MYOFIBROBLASTS AT THE ULCER MARGIN

The number of capillaries and myofibroblasts in the granulation tissue at the ulcer margin in vehicle treated rats were $16(0.8)$ and $104(6)$ respectively (Table III). Intragastric administration of bFGF caused a significant increase in capillaries but not myofibroblasts. Treatment with sucralfate did not significantly alter the number of capillaries or myofibroblasts. In rats injected intraperitoneally with bFGF, the number of capillaries almost doubled and the number of myofibroblasts was significantly increased (by about $30 \%$ ). The combination of bFGF plus sucralfate resulted in similar increase in capillaries and myofibroblasts to those with bFGF alone.

EFFECTS OF SUCRALFATE AND INDOMETHACIN ON BINDING OF [ ${ }^{125}$ I] bFGF TO THE INTACT AND

ULCERATED MUCOSA

Figure 1 shows distribution of $\left[{ }^{125} I\right] \mathrm{bFGF}$ between the ulcer area and adjacent intact mucosa presented as the radioactivity ratio (ulcer area $v$ intact mucosa). There were small but measurable amounts of [ $\left.{ }^{125} \mathrm{I}\right] \mathrm{bFGF}$ bound to the intact mucosa and treatment with sucralfate for seven days did not significantly influence this. By contrast, the ulcer area accumulated about twofold more labelled bFGF in vehicle treated rats and about threefold more in sucralfate treated animals. The addition of indomethacin resulted in a significant decrease in the radioactivity ratio between ulcerated and intact mucosa. A similar distribution of labelled FGF between the ulcer area and the intact mucosa was found after in vitro exposure and these results have not been included.

Labelled bFGF added in vitro to the suspension of sucralfate adjusted to $\mathrm{pHs}$ ranging from 7.0 to 2.0 was bound in gradually increasing amounts with decreasing $\mathrm{pH}$. At $\mathrm{pH} 7 \cdot 0$ about $10 \%$ of total radioactivity of $\left[{ }^{125} \mathrm{I}\right] \mathrm{bFGF}$ was bound to sucralfate, whereas at $\mathrm{pH} 2 \cdot 0$ the binding increased to about $90 \%$ (Fig 2).

EFFECTS OF BFGF AND SUCRALFATE ON NUCLEIC ACID CONTENT IN THE GASTRIC MUCOSA

In intact rats without induction of gastric ulcers, the values of DNA synthesis and DNA or RNA concentrations in oxyntic mucosa averaged 30.3 (2.0) dpm/ $\mu \mathrm{g}$ DNA, $371(34) \mu \mathrm{g} / 100 \mathrm{mg}$, and $1062(60) \mu \mathrm{g} / 100 \mathrm{mg}$ respectively. After induction of acetic acid ulcerations and seven day administration of vehicle in rats of series $A$, the values of DNA synthesis and nucleic acid concentrations in the intact mucosa opposite to the ulcer area were not significantly different from the control values (Table IV). By contrast, the mucosa resected from the ulcer margin, including the granulation tissue, showed significantly higher DNA synthesis and higher DNA and RNA concentrations.

Treatment with bFGF almost doubled the DNA synthesis at the ulcer margin and in the non ulcerated mucosa. The DNA and RNA concentrations were also significantly increased (compared with vehicle control) both in the ulcer margin and in the adjacent non-ulcerated mucosa. Treatment with sucralfate alone $(400$ $\mathrm{mg} / \mathrm{kg}$ ) did not significantly alter DNA synthesis and the concentrations of nucleic acid in the ulcer margin or in the adjacent intact mucosa. The addition of bFGF to sucralfate resulted in similar stimulation in DNA synthesis and in similar increases in the concentrations of DNA

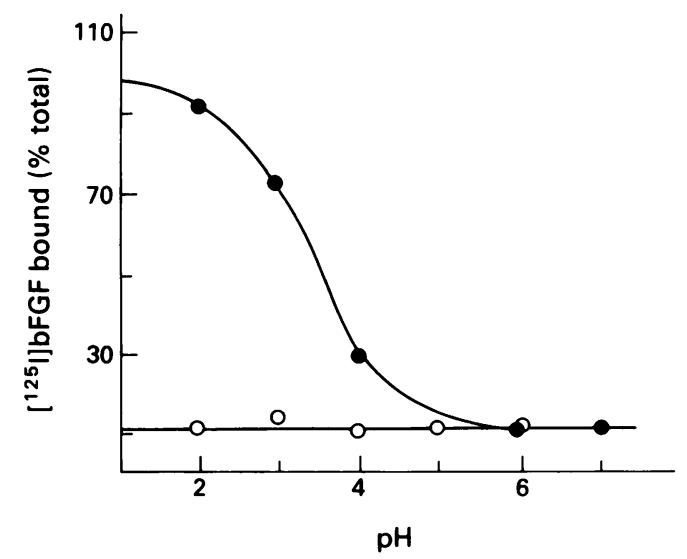

Figure 2: Coprecipitation of [125 I $] b F G F$ by sucralfate $(20 \mathrm{~g} / \mathrm{l})(\mathrm{O})$ or vehicle $(\mathrm{O})$ adjusted to $\mathrm{pH}$ s ranging from $2 \cdot 0$ to $7 \cdot 0$. 
TABLE IV Synthesis of DNA and DNA and RNA concentration in the stomach after development of ulcers and treatment with vehicle, $b F G F(30 \mu g / k g / d a y)$, sucralfate $(400 \mathrm{mg} / \mathrm{kg} /$ day $)$, or a combination of $b F G F$ and sucralfate

\begin{tabular}{|c|c|c|c|c|c|c|}
\hline & Vehicle & $\begin{array}{l}b F G F \\
(i g)\end{array}$ & $\begin{array}{l}b F G F \\
(i p)\end{array}$ & Sucralfate & $\begin{array}{l}\text { bFGF (ig) } \\
+ \text { sucralfate }\end{array}$ & $\begin{array}{l}\text { bFGF(ip) } \\
+ \text { sucralfate }\end{array}$ \\
\hline \multicolumn{7}{|c|}{ Ulcer margin } \\
\hline $\begin{array}{l}\text { DNA synthesis (dpm/ } / \mu \mathrm{g} \text { DNA) } \\
\text { DNA ( } \mu \mathrm{g} \text { DNA } 100 \mathrm{mg}) \\
\text { RNA ( } \mu \mathrm{g} \text { RNA } / 100 \mathrm{mg})\end{array}$ & $\begin{array}{l}45 \cdot 0(3 \cdot 5)^{\star} \\
470(26)^{\star} \\
1482(93)^{\star}\end{array}$ & $\begin{array}{l}86 \cdot 0(11 \cdot 4) \dagger \\
567(22) \dagger \\
1807(116) \dagger\end{array}$ & $\begin{array}{l}96 \cdot 0(8 \cdot 0) \dagger \\
565(16) \dagger \\
1690(95) \dagger\end{array}$ & $\begin{array}{l}44 \cdot 0(2 \cdot 5)^{\star} \\
470(49)^{\star} \\
1370(57)^{\star}\end{array}$ & $\begin{array}{l}68 \cdot 0(4 \cdot 3) \dagger \\
514(42) \\
1630(56)\end{array}$ & $\begin{array}{l}88 \cdot 2(3 \cdot 8) \dagger \\
528(57) \dagger \\
1660(110) \dagger\end{array}$ \\
\hline \multicolumn{7}{|c|}{ Intact mucosa } \\
\hline $\begin{array}{l}\text { DNA synthesis }(\text { dpm/ } / \mu \mathrm{g} \text { DNA) } \\
\text { DNA }(\mu \mathrm{g} / \mathrm{DNA} / 100 \mathrm{mg}) \\
\text { RNA }(\mu \mathrm{g} \text { RA/100 mg) }\end{array}$ & $\begin{array}{l}38 \cdot 0(3 \cdot 6) \\
395(16) \\
1117(71)\end{array}$ & $\begin{array}{l}68 \cdot 0(2 \cdot 9) \dagger \\
472(24) t \\
1689(148) \dagger\end{array}$ & $\begin{array}{l}60 \cdot 0(4 \cdot 9) \dagger \\
500(35) \dagger \\
1410(19) \dagger\end{array}$ & $\begin{array}{l}39 \cdot 0(6 \cdot 9) \\
406(45) \\
1160(45)\end{array}$ & $\begin{array}{l}55 \cdot 7(3 \cdot 4) \dagger \\
494(12) \dagger \\
1586(93) \dagger\end{array}$ & $\begin{array}{l}66 \cdot 0(2 \cdot 9) \dagger \\
483(12) \dagger \\
1505(88) \dagger\end{array}$ \\
\hline
\end{tabular}

^Significant change compared with intact mucosa.

†Significant change compared with vehicle control.

ig=Intragastric; ip=intraperitoneal.

and RNA to those in rats treated with bFGF without sucralfate (Table IV).

\section{Discussion}

This study provides evidence that bFGF given parenterally or by an intragastric route is not protective against the acute gastric lesions induced by topical irritants such as ethanol or aspirin but exerts a significant protection against the stress induced lesions and considerably enhances the healing rate of chronic gastric ulcers. Addition of sucralfate to bFGF does not influence the gastroprotective properties but augments the ulcer healing action of this drug.

The presence of $\mathrm{bFGF}$ and the binding sites for this peptide have been documented in various tissues including the gastrointestinal $\operatorname{tract}^{10}{ }^{12}$ but the physiological role of bFGF has not previously been established. This study shows that bFGF, unlike EGF or $\mathrm{TGF}_{\alpha}$, does not affect gastric acid secretion or gastric blood flow, the major factors that have been implicated in mucosal protection against topical irritants. This probably explains the failure of bFGF to protect the gastric mucosa against the damage caused by absolute ethanol and acidified aspirin. Only in rats subjected to stress did bFGF (given subcutaneously in a large dose) cause a small but significant attenuation of the mucosal lesions and this was accompanied by increased gastric blood flow suggesting that the maintenance of gastric circulation in stressed rats could explain this protection. Other mechanisms, however, such as stimulation of cell migration and proliferation are not excluded.

Sucralfate was effective against all three types of mucosal lesions. This was probably due to the stimulation of mucosal defence mechanisms ${ }^{26}$ and to the increase in mucosal blood flow that has been recognised previously ${ }^{27}$ and attributed recently to the formation of nitric oxide, a potent locally acting vasorelaxing factor. ${ }^{28}$ As expected, the addition of bFGF to sucralfate did not augment the gastroprotective activity of this drug except in stress lesions, which were significantly more reduced after treatment with the combination of bFGF and sucralfate than with each agent separately.

The most important finding is that bFGF given parenterally or applied directly to the mucosa enhanced the healing of acetic acid induced gastric ulcerations and augmented the healing activity of sucralfate. These effects of
bFGF have been documented with our modification of chronic gastric ulceration induced by serosal application of acetic acid that is now widely used in studies of the efficacy of various antiulcer drugs. ${ }^{242932}$ These ulcers heal spontaneously and rapidly so that seven days after their induction the ulcer area was usually reduced to about $30 \%$ of its initial size.

The mechanism of the healing is unknown but previous studies showed that the new vacularisation at the ulcer margin, ${ }^{31} 32$ the establishment of adequate blood flow around the ulcer base, ${ }^{33}$ and stimulation of cell migration and proliferation in the granulation tissue at the ulcer bed ${ }^{6}$ are the key factors in this process. Agents that inhibit gastric acid secretion enhance the healing ${ }^{30}$ and this was also confirmed in our study because omeprazole at a dose that almost completely inhibited gastric acid secretion was effective in promoting ulcer healing. Our study shows that bFGF, even at a dose that did not affect gastric acid secretion ( $30 \mu \mathrm{g} / \mathrm{kg} /$ day), was also effective in healing these lesions. Obviously, this healing effect could not be mediated by the inhibition of acid secretion and other mechanisms are involved in the healing process. Administration of bFGF strongly stimulated DNA synthesis, especially in the granulation tissue at the ulcer margin, and increased DNA and RNA content in the adjacent intact mucosa. Detailed histological assessment showed a significant increase in the number of capillaries and fibroblasts in the granulation tissue of rats treated with bFGF compared with that in vehicle treated controls. Cell migration and proliferation and angiogenesis could all contribute to the ulcer healing activity of bFGF. The stimulation of new microvessel formation was postulated as it is the major mechanism of action of FGF on gastric ulcers $^{31}$ and of acid resistant bFGF on healing acetic acid induced gastric ulcer and cysteamine induced duodenal ulcers in rats. ${ }^{190}$

It is of interest that sucralfate alone was also effective in speeding the healing rate of gastric ulcers and this is in keeping with previous studies on ulcer healing properties of this drug in animal models ${ }^{29}$ and in humans. ${ }^{34}{ }^{35}$ In acidic gastric milieu, sucralfate is a polyvalent anion, electrostatically binding most protein molecules (preferentially in the ulcer base) that are positively charged. ${ }^{26}{ }^{36}$ Also, sucralfate was found in this study to bind labelled bFGF in vitro in a $\mathrm{pH}$ related manner. This suggests accumulation of bFGF to the ulcer area to form a reservoir of 
bFGF that could be responsible for the enhancement of angiogenesis ${ }^{1619}$ and mucosal growth (increased DNA and RNA) in the ulcer margin seen in rats treated with the combination of bFGF plus sucralfate. The growth indices at the ulcer margin in rats treated with sucralfate alone were, however, not significantly different from those in vehicle treated animals indicating that endogenous growth factors such as EGF and $\mathrm{TGF}_{\alpha}$ released locally from the injured mucosa ${ }^{37}$ may be sufficient to drive the cell proliferation at the ulcer margin. An additional supply of exogenous bFGF accelerated the ulcer healing probably due to the increased angiogenesis and the proliferation of cells such as myofibroblasts in the granulation tissue. It is of interest that the addition of intragastric bFGF to sucralfate did not cause any further decrease in ulcer size despite the increase in DNA synthesis at the ulcer margin. This indicates that the stimulation of cell proliferation may not be the only factor in ulcer healing by sucralfate. When sucralfate was combined with another growth factor (EGF) no additive effects on healing of acetic acid induced gastric ulcers were found either..$^{38}$

In summary, bFGF administered orally or given parenterally accelerated the healing of acetic acid induced gastric ulcers in rats. The healing affect was dose dependent and, at a dose that did not affect gastric secretion, was comparable with that achieved with omeprazole, a potent inhibitor of gastric secretion. The ulcer healing by bFGF seems to involve angiogenesis and cell proliferation, especially at the ulcer margin, and is enhanced by treatment with sucralfate.

1 Burgess AW, Sizerland AM. Growth factors and the gut. $\mathcal{F}$ Gastroenterol Hepatol 1990; 5 (suppl 1): 10-21.

2 Westermark B, Betsholts C, Hokfelt B. Growth factors in health and disease. Basic and clinical aspects. Amsterdam: Excerpta and disease. Besic

3 Konturek SJ, Radecki T, Brzozowski T. Gastric cytoprotection by epidermal growth factor. Role of endogenous prostaglandin and DNA synthesis. Gastroenterology 1981; 81: $438-44$.

4 Olsen SP, Paulsen SS, Kirkegaard P, Nexo E. Role of submandibular saliva and epidermal growth factor in gastric cytoprotection. Gastroenterology $1984 ; 87$ : 103-8.

5 Konturek SJ, Brzozowski T, Majka J, Slomiany B. Transforming growth factor alfa and epidermal growth factor in protection and healing of gastric mucosal injury. Scand $\mathcal{F}$ Gastroenterol (in press)

6 Konturek SJ. Role of growth factors in gastroduodena protection and healing of peptic ulcers. Gastroenterology protection and healing of peptic ulcers.
Clinics of North America 1990; 19: 41-65.

7 Nexo E, Poulsen SS. Does epidermal growth factor play a role in the action of sucralfate? Scan $\mathcal{F}$ Gastroenterol 1987; 22 (suppl 127): 45-9.

8 Konturek SJ, Brzozowski T, Bielanski W, Warzecha Z, Drozdowicz D. Epidermal growth factor in the gastroprotective and ulcer-healing actions of sucralfate in rats. $A m \mathcal{F}$ Med 2989; 86 (suppl 6A): 32-7.

9 Konturek SJ, Brzozowski T, Drozdowicz D, Dembinski A Nauert Ch. Healing of chronic gastroduodenal ulcer by antacids. Role of prostaglandins and epidermal growth factor. Dig Dis Sci 1990; 35: 1121-9.

10 Baird A, Esch F, Mormede P, Veno N, Ling N, Bohlem P, et al. Molecular characterization of fibroblast growth factor: distribution and biological activities in many tissues. Recent Prog Horm Res 1986; 42: 143-205.

11 Gospodarowicz D. Fibroblast growth factor. Clin Orthop 1990; 257: $231-48$.

12 Cordon-Cardo C, Vlodavsky I, Haimovitz-Friedman A, Aicklin D, Fuks Z. Expression of basic growth factors in normal human tissues. Lab Invest 1990; 63: 832-40.
13 Schweigerer L, Neufeld G, Friedman J, Abraham J, Fiddes J, Gospodarowicz D. Capillary endothelial cells express basis fibroblast growth factor, a mitogen that promotes their own growth. Nature 1987; 325: 257-9.

14 Baird A, Mormede P, Bohler P, Immunoreactive fibroblast growth factor in cells of peritoneal exudates suggests its identity with macrophages-derived growth factor. Biochem Biophys Res Commun 1985; 126: 358-64.

15 Vlodavsky I, Folkman J, Sullivan R. Endothelial cell-derived basic fibroblast growth factor: synthesis and deposition into subendothelial extracellular matrix. Proc Natl Acad SciUSA 1987; 84: 2292-6.

16 Folkman J, Klagsbrum M, Sasse I, Wadzinski M, Ingberg D, Vlodavsky I. A heparin binding angiogenic protein - basic fibroblast growth factor - is stored within basement fibroblast growth factor - is stored with

17 Nakamura $M$, Oda $M$, Inoue J, Ito T, Tsuchiya $M$. Interaction of fibroblast growth factor to the myofibroblast induced by acetic acid mediated ulcer. Gastroenterology 1991; 100: A131.

18 Hannson H-A, Norstrom E. FGF, EGF and their receptors in the normal and healing rat gastric mucosa. Digestion 1991; 49 (suppl 1): 17-8.

19 Folkman J, Szabo S, Vattay P, Morales R, Pinkus G, Kato K. Effect of orally administered bFGF on healing of chronic duodenal ulcers, gastric secretion and acute mucosal lesions. Gastroenterology 1990; 98: A45.

20 Satoh H, Shino A, Inatomi N, Nagaya H, Sate F, Szabo S. Effects of rhbFGF mutein CS23 (TGP-580) on the healing of gastric ulcers induced by acetic acid in rats. Gastroenterology gastric ulcers ind

21 Esch F, Baird A, Ling N. Primary structure of bovine pituitary basic fibroblast growth factor (FGF) and comparison with the amino-terminal sequence of bovine brain acidic FGF. Proc Natl Acad Sci USA 1985; 82: 6507-11.

22 Takeuchi K, Okabe S, Takagi K. A new model of stress ulcers in rats with pylorus ligation and its pathogenesis. American fournal of Digestive Diseases 1997; 21: 742-88.

23 Chung SCS, Leung JWC, Leung FW. Effect of submucosal epinephrine injection on local gastric blood flow. A study epinephrine injection on local gastric blood flow. A study using laser Doppler flowmetry and reluct
photometry. Dis Dis Sci 1990; 35: 1008-11.

24 Takagi K, Okabe S, Saziki R. A new method for the production of chronic gastric ulcers in rats and the effects of several drugs on its healing. $\mathcal{F p n} \mathcal{F}$ Pharmacol 1969; 19: 41826.

25 Dembinski A, Gregory H, Konturek SJ, Polanski M. Trophic action of epidermal growth factor on the pancreas and gastrointestinal mucosa. F Physiol 1982; 325: 35-42.

26 Tarnawski A, Erickson A. Sucralfate - 24 years later: curren concepts of its protective and therapeutic actions. Current Science 1991; 3: 795-810.

27 Hui WM, Chen BW, Cho Ch, Luk CT, Lam SK. Role of gastric mucosal blood flow in cytoprotection. Digestion 1991 48: 113-20.

28 Konturek SJ, Brzozowski T, Majka J, Czarnobilski K. Role of nitric oxide and prostaglandins in sucralfate-induced gastroprotection. Eurf Pharmacol 1992; 221: 277-9.

29 Konturek SJ, Stachura J, Radecki T, Drozdowicz D, Brzozowski T. Cytoprotective and ulcer healing properties of prostaglandin $\mathrm{E}_{2}$, colloidal bismuth and sucralfate in rats. Digestion 1987; 38: 103-17.

30 Wang JY, Nagai H, Okabe S. Effect of omeprazole on delayed healing of acetic acid-induced gastric ulcers in rats. $\mathcal{F} p n \mathcal{F}$ Pharmacol 1990; 54:82-5.

31 Hase S, Nakazawa S, Tsukamoto Y, Segawa K. Effects of prednisolone and human epidermal growth factor on angiogenesis in granulation tissue of gastric ulcer induced by acetic acid. Digestion 1987; 38: 103-17.

32 Tarnawski A, Hollander D, Stachura J, Krause WJ, Eltorai $M$, Dabros W, Gergely $H$. Vascular and microvascular changes - key factors in the development of acetic acidinduced gastric ulcers in rats. $\mathcal{F}$ Clin Gastroenterol 1990; 12 : S148-57.

33 Hirose H, Takeuchi K, Okabe S. Effect of indomethacin on gastric mucosal blood flow around acetic acid-induced gastric ulcers in rats. Gastroenterology 1991; 100: 1259-65.

34 Hollander D. Efficacy of sucralfate for duodenal ulcers; a multicenter, double-blind trial. $\mathcal{f}$ Clin Gastroent 1981; 3 (suppl 2): 153-7.

35 McHardy GG. A multicenter, double-blind trial of sucralfate and placebo in duodenal ulcer. 7 Clin Gastroenterol 1981; 3 (suppl 2): 147-52.

36 Nagashima R. Mechanism of action of sucralfate. $\mathcal{f}$ Clin Gastroenterol 1981; 3 (suppl 2): 117-27.

37 Polk WH, Dempsey PJ, Russal WE, Brown PI, Beaucham $\mathrm{RD}$, Bernard JSA, et al. Increased production of transforming growth factor alpha following acute gastric injury. ing growth factor alpha following

38 Konturek SJ, Brzozowski T, Warzecha Z, Drozdowicz D. Epidermal growth factor in the gastroprotective and ulcerEpidermal growth factor in the gastroprotective and ulcer-
healing actions of sucralfate in rats. Am $₹ \mathrm{Med} 1989 ; 86$ (suppl 6A): 32-7. 